\title{
Introduction to the Special Issue on Field Education of Students
}

\author{
Marion Bogo ${ }^{1}\left[\right.$ ] Karen M. Sewell ${ }^{1}$ \\ Published online: 6 December 2018 \\ (c) Springer Science+Business Media, LLC, part of Springer Nature 2018
}

\begin{abstract}
Two Special Issues of the Clinical Social Work Journal have been dedicated to building on the social work discipline's tradition and commitment to the supervision of staff and field education of students. The first issue included papers on the supervision of professional social work staff. The focus of this issue is field education of students, the signature pedagogy of social work (CSWE in Educational policy and accreditation standards, CWSE, Alexandria, 2008, 2015a). Attention is given to macro structural issues impinging on the profession's capacity to provide quality learning experiences, in addition to the integration of concepts into our educational practices, and research studies that provide systematic approaches to training practicing field instructors and providing clinical supervision for students. In this Introduction, we share the salient aspects of the articles published, as they relate to contemporary field education, with implications to guide field instructors as they provide learning experiences for students.
\end{abstract}

Keywords Field education · Supervision of students $\cdot$ Practice learning $\cdot$ Special issue $\cdot$ Social work $\cdot$ Signature pedagogy

"Field is the heart of social work education" (NANFED, n.d.). This declaration by the North American Network of Field Educators and Directors (NANFED) captures the sentiment of many students and alumnae. That it is in the field where we truly learn to $b e$ a social worker. Indeed, the Council on Social Work Education (CSWE) recognized this phenomenon and in the Educational Policy and Accreditation Standards (EPAS) for schools of social work designated field education as the signature pedagogy of social work in 2008, and reaffirmed the statement in 2015 (CSWE 2008, 2015a). Education scholar and theorist Lee Shulman coined the phrase signature pedagogy to refer to the fundamental and distinct ways in which each profession instructs and socializes students "to think, to perform, and to act ethically and with integrity" (Shulman 2005, p. 52). EPAS states:

The intent of field education is to connect the theoretical and conceptual contribution of the classroom with the practical world of the practice setting. It is a basic precept of social work education that the two interrelated components of curriculum-classroom and

Marion Bogo

marion.bogo@utoronto.ca

1 Factor-Inwentash Faculty of Social Work, University of Toronto, 246 Bloor St. West, Toronto, ON M5S 1V4, Canada field-are of equal importance within the curriculum, and each contributes to the development of the requisite competencies of professional practice. (CSWE 2015a, b p. 12).

Furthermore, since social work education contributes to the quality of social work services delivered to the public, field education has a pivotal role in preparing social workers who can provide effective service to clients. It is not sufficient for students to learn about conceptual knowledge, emerging empirical findings, and values. They must learn to integrate and apply these dimensions through skillful and intentional practices. In this way our graduates can address the complex and diverse needs presented in contemporary societies.

And yet, despite these strong aspirational statements about the importance of field, there is concern that quality field education opportunities for our students are not as robust as they once were. The Field Summit convened by the CSWE in 2014 provided a cogent analysis of external and internal factors with recommendations for change (CSWE 2015b). The 2015 State of Field Education Survey Final Report highlights that "contextual factors such as changing student demographics, the state of the economy, agency environments and staff turnover, students as consumers, students' competing obligations, and students' 
economic statuses all create complexities that are not easily addressed." (CSWE 2015b, p. 4).

Keenly aware of these challenges to excellence in clinical social work field education opportunities, we were eager to respond when the Editor-in-Chief of The Clinical Social Work Journal invited us to serve as Guest Editors for the Special Issues on the Supervision of Social Work Staff and Field Education of Students. Part One of the Special Issues consists of papers on the supervision of social work staff. This Issue, Part Two, consists of papers on the field education of students. We were encouraged by the substantial response to the Call for Papers, mainly from faculty members and Directors of Field Education. Reviewing the submissions we concluded that there is considerable interest in contributing to the knowledge base of field education. The papers selected for inclusion represent a wide range of scholarship including current and historical analysis of issues and challenges, contemporary theorizing, field education practice experience, and research studies - all of which provide approaches, insights, and practices that will be useful for clinical social workers as they provide field education.

A recurrent theme running through many of the papers relates to the challenges of finding and maintaining quality field practicum settings and committed, available field educators who understand the dynamics of teaching and learning, and use effective approaches. This Special Issue begins with three papers that address aspects of this theme. Farber and Reitmeier provide a review and analysis of the origins of conceptualizing teaching in the field, reminding us of the wisdom of the founding leaders of the profession, and providing important lessons from history at risk of being lost. This paper also examines current issues and provides useful recommendations to recapture the enduring principles of field education which remain as important today in learning for the profession. Gushwa and Harriman contribute to this macro theme as they identify the impact of increasing numbers of social work programs, field agencies faced with tightening budgets, and an overtaxed workforce. Written as a dialogue between a Director of an MSW Program and a Director of Field Education the authors raise crucial questions they hope will stimulate creative thinking for the profession. The third paper in this section comes from New Zealand where Hay, Maidment, Ballantyne, Beddoe, and Hay report findings from their study of educators' and students' perceptions of the field experience. Of interest to North American educators is that students take a course on supervision prior to entering the field. The authors found that many students reported irregularity in their field education experience and associated receiving quality supervision with "being lucky." This paper echoes themes identified in Gushwa and Harriman's paper, "Paddling Against the Tide". These cogent phrases capture unfortunate conditions currently associated with field experiences internationally.
The next group of papers address models for field education. Two papers address the structure of field models. From Australia, Cleak and Zuchowski identify the crisis facing schools of social work and provide an analysis of additional field instruction models used to supplement the traditional and preferred approach of each student having one field instructor. Using a framework of best practices developed by Bogo (2015), they analyze alternate models such as the use of external supervision, group supervision, rotational supervision, and co-supervision. The next paper by Greenblatt, Muskat, and Perlman from Canada provides a study of one of these models, the rotational model. Their findings indicate that the rotational model has increased in use over the past decade in their locale. Qualitative data from field instructors provide insight into how the model can be used to maximize its effectiveness.

Training field instructors to supervise students' learning of evidence-supported interventions, specifically screening, brief intervention and referral to treatment (SBIRT) and motivational interviewing, is the focus of the next paper. Egizio, Smith, Bennett, Campbell, and Windsor describe components of a supervisory training model: didactic training, coaching, and in person visits to agencies providing field education. The positive results from this study support a training approach that could be used in field education with other intervention models.

The next four papers focus on process issues in field education, including attention to trauma. In the first of this group, Shea presents a model of reflective supervision, a relationship-based model, used extensively in the field of infant mental health. The paper offers an in depth account of the educational principles of the approach, and an informative example of its application in a 9-month process-oriented reflective supervision group for social work field instructors. A compelling case example brings the concepts to life. Continuing the focus on process, in the next paper Solo uses recent conceptualizations of emerging adulthood to illuminate aspects of professional identity and "use of self". Since many social work students are young adults in their early to late twenties this lens provides an expanded understanding of the development of personal and professional identity, including challenges to learning in the field.

Clinical social work scholars and practitioners increasingly recognize the impact of trauma on both clients and practitioners. Accordingly, approaches to trauma-informed practice and care need to be integrated into social work education and preparation of new graduates. Knight provides a comprehensive paper with insights and recommendations to accomplish this goal. Case examples provide clear illustrations of how concepts regarding trauma are pertinent for field education practice. In the following paper, Tarshis and Baird bring the lens of trauma to those practicing with clients experiencing intimate partner violence (IPV). They 
systematically review the relevant literature noting that social workers, as well as social work students, are at risk of indirect trauma since they may not have received preparation about coping with exposure to trauma. The paper defines key concepts and provides a framework for clinical supervision of students with examples drawn from their experiences providing field instruction to MSW students.

In 2008 and again in 2015, the CSWE's EPAS (CSWE 2008, 2015a) articulated the expectation that accredited schools develop rigorous approaches to educational outcomes assessment. Research and scholarship in this area have been slow to develop and we are pleased to provide two papers on this topic. In the first paper from England, Domakin describes an innovative, fast-track educational program, Frontline. Designed to educate highly skilled child and family social workers, students' learning is primarily conducted in agency settings. Students' practice is regularly observed, with seven graded observations of practice in child welfare contexts. The paper summarizes findings based on studies of these observations and introduces a novel concept, "consensus discussion" to address differences in ratings between various graders.

In the second paper on assessment, Turner, Strand, Bliss, and Sacristan report on a study of general and specific competencies which students in a clinical MSW program are expected to achieve. They compare students' and field instructors' perceptions identifying similarities and differences in relation to what students learn and where it is learned. Drawing from their findings, these authors reiterate the need for close coordination between universities and field agencies to align what programs expect students to learn, and the capacity of field instructors to teach those competencies.

The final two papers in this Special Issue report on studies in contexts similar in many respects to field education. From their studies, the authors extract educational principles and practices that are useful not only for their particular situations, but also that can be transferred into field education. Kourgiantakis, Sewell, and Bogo report on a study of students' learning in simulation-based education. Specifically, they illuminate the impact of feedback on students' learning and propose a systematic set of principles for field education: articulating clear competencies, identifying focused practice opportunities, observation of students' practice, guiding students' reflections, and providing specific, immediate, constructive feedback related to the competencies.

In the following paper Radey, Schelbe, and King present a study that examined the value and impact of field day training experiences for new child welfare workers. The study reveals conditions and practices that facilitate learning in a setting similar to that of the field practicum. Their findings support the importance in field education of integrating knowledge from classrooms into practice, creating structure for field learning, engaging with experienced social workers, and offering supportive learning environments.

This Special Issue continues to reiterate the importance of field education for the preparation of the next generation of social workers, and draws attention to the macro structural challenges impinging on the profession's capacity to provide effective field education. As the recent Field Education Survey: Final Report eloquently states: "Because students become practitioners, the functioning of social systems, the needs of clients and consumers, and the fabric of society are at stake" (CSWE 2018, p. 6). While there is clearly concern expressed about the viability of current field education arrangements, there are also many social work educators committed to realizing the aspirations in the designation of field as the signature pedagogy of social work. The conceptual contributions, rigorous studies, and creative practices revealed in the papers in this Special Issue demonstrate that field education is increasingly an evidence-informed practice, and education scholars and researchers are creating evidentiary support for long-standing and emerging concepts, principles, and practices. Indeed, it is likely the pedagogical activity in social work education that has received the most research and scholarly attention. We are gratified that this Special Issue contributes to this knowledge base.

\section{References}

Bogo, M. (2015). Field education for clinical social work practice: Best practices and contemporary challenges. Clinical Social Work Journal, 43(3), 317-324.

Council on Social Work Education. (2008). Educational policy and accreditation standards (Rev. ed.) (EPAS). Alexandria, VA: CSWE. Retrieved from http://www.cswe.org/File.aspx?id=13780.

Council on Social Work Education. (2015a). Educational policy and accreditation standards (EPAS). Alexandria, VA: CSWE. https:// www.cswe.org/getattachment/Accreditation/Accreditation-Proce ss/2015-EPAS/2015EPAS_Web_FINAL.pdf.aspx.

Council on Social Work Education. (2015b). Report of the CSWE summit on field education 2014. Alexandria, VA: CSWE. Retrieved from http://www.cswe.org/File.aspx?id=79746 (https://www. cswe.org/getattachment/05519d2d-7384-41fe-98b8-08a21682ed 6e/State-of-Field-Education-Survey-Final-Report.aspx).

Council on Social Work Education. (2018). Field education survey. Final report. Alexandria, VA: CSWE. https://www.cswe.org/ getattachment/05519d2d-7384-41fe-98b8-08a21682ed6e/State -of-Field-Education-Survey-Final-Report.aspx.

North American Network of Field Educators and Directors (n.d.). Retrieved from https://nanfed.com.

Shulman, L. S. (2005). Signature pedagogies in the profession. Daedalus, 134(3), 52-59.

Publisher's Note Springer Nature remains neutral with regard to jurisdictional claims in published maps and institutional affiliations. 
Marion Bogo is Professor at the Factor-Inwentash Faculty of Social Work, University of Toronto, Toronto, Canada. Her scholarship and research focuses on social work education for practice, particularly conceptualization and assessment of holistic competence and field education.

Karen M. Sewell is a PhD candidate, course instructor, and research coordinator at the Factor-Inwentash Faculty of Social Work, University of Toronto. She has experience as a field instructor and faculty-field liaison. Her research focuses on clinical supervision, informed by clinical experience in child/youth mental health. She is involved in social work education research on holistic competence, and simulation. 